\title{
The Epidemiology of Cardio-Vascular Diseases in Relation to the Air Quality of Abattoirs in Port Harcourt, Nigeria
}

\author{
Vincent Ezikornwor Weli1 ${ }^{*}$, Jimmy O. Adegoke², Meelubari Barinua Kpang2 \\ ${ }^{1}$ Department of Geography and Environmental Management, Faculty of Social Sciences, University of Port \\ Harcourt, Port Harcourt, Nigeria \\ ${ }^{2}$ Department of Geosciences, University of Missouri, Kansas City, USA \\ Email: wwelivinezi@yahoo.com,kpangdemelus@ymail.com,adegokej@umkc.edu
}

Received 17 February 2016; accepted 26 April 2016; published 29 April 2016

Copyright (C) 2016 by authors and Scientific Research Publishing Inc.

This work is licensed under the Creative Commons Attribution International License (CC BY). http://creativecommons.org/licenses/by/4.0/

(c) () D Den Access

\begin{abstract}
This study investigated the spatial occurrence of cardiovascular diseases associated with the air quality of selected abattoirs in Port Harcourt. Using the simple random sampling technique, the Trans-Amadi, Rumuokoro, Rukpokwu and Elelenwo abattoirs were selected and used for the study. However, both gases and particulates matter which include $\mathrm{NO}_{2}, \mathrm{SO}_{2}, \mathrm{H}_{2} \mathrm{~S}, \mathrm{CH}_{4}, \mathrm{CO}_{1} \mathrm{PM}_{2.5}$, and $\mathrm{PM}_{10}$ were collected at distances of $0,20,50,100,200 \mathrm{~m}$ with the aid of a hand held multi-gas monitor. The questionnaire was used to obtain the demographic and socio-economic characteristics of the respondents, duration of job in years, as well as individual frequency of hospital visitation based on symptoms of cardiovascular diseases. The electrocardiogram was employed to diagnose manifestations of ischemic heart disease among the workers especially in the roasting section. Analysis of data collected was done using the Step-wise multiple regression technique. Result showed that occurrence of cardiovascular diseases is a function of pollutant concentration (CO $-\mathbf{r}=$ 0.57) at Rumuokoro abattoir; $\left(\mathrm{O}_{3}-\mathrm{r}=0.40, \mathrm{SO}_{2}-\mathrm{r}=0.23, \mathrm{CO}-\mathrm{r}=0.14\right)$ at Rukpokwu abattoir, duration of exposure (DOE $-r=0.22$ ) at Rumuokoro abattoir, (DOE $-r=0.40)$ at Trans-Amadi abattoir; and (DOE $-r=0.20)$ at Elelenwo abattoir; age of worker $(r=0.06)$ at Rukpokwu abattoir, $(r=$ 0.30 ) at Elenlewo abattoir and daily duration on the job (JOBD $-r=0.13$ ) at Elelenwo abattoir. Findings indicate that there is a positive correlation between occurrence of vascular diseases and pollutant concentration, duration of exposure, age and duration on the job but varies from location to location. Periodic epidemiological and air quality assessment of workers at the abattoirs are strongly advocated.
\end{abstract}

\section{Keywords}

Abattoir, Cardiovascular Diseases, Air Quality, Pollutant Concentration, Duration of Exposure

\footnotetext{
${ }^{*}$ Corresponding author.

How to cite this paper: Weli, V.E., Adegoke, J.O. and Kpang, M.B. (2016) The Epidemiology of Cardio-Vascular Diseases in Relation to the Air Quality of Abattoirs in Port Harcourt, Nigeria. World Journal of Cardiovascular Diseases, 6, 94-107. http://dx.doi.org/10.4236/wjcd.2016.64011
} 


\section{Introduction}

The use of tires for the roasting of hides and skin with its abundant thick smoke emitting in the vicinity of abattoirs in Nigeria is a common practice which has attracted serious attention from air quality experts in Nigeria. Potential emissions to air commonly associated with the incineration of animal carcases include particulate matter; hydrogen chloride; oxides of Sulphur, nitrogen and carbon and organic compounds, such as dioxins. Outdoor air pollution, composed of complex mixtures including gases (e.g., carbon monoxide (CO), nitrogen dioxide $\left(\mathrm{NO}_{2}\right)$, ozone $\left(\mathrm{O}_{3}\right)$, sulfur dioxide $\left(\mathrm{SO}_{2}\right)$, and particulate matter $(\mathrm{PM})$, is increasingly considered a new threat to the cardiac system [1]-[4]. It is manifested by endothelial dysfunction, hypertension, and increased thrombogenic and inflammatory state [5]. Scientist noticed as early as the 1920s and 1930s the impact of air pollution on human health: High rates of death events occurred in London and Belgium after stagnant weather conditions caused by a sharp increase in the concentration of air pollutants for many days [6]. Literature uncovered the fact that even shy amounts of exposure to pollutants can have deleterious effects on the health in terms of morbidity and mortality [2] [7]-[12]. Several epidemiological studies on air pollution and cardiovascular diseases (CVD) are from developed countries [2] [3] [13]; unfortunately, this has been less investigated in developing countries, although they have similar or higher pollutant concentrations [14] [15]. One type of wastes that is of great concern in both urban and rural areas in Nigeria is abattoir or slaughter-house wastes. Almost every day in all the urban and rural markets in Nigeria, animals are slaughtered and the meat sold to the public for consumption. Meat wastes originate from killing; hide removal or dehairing, paunch handling, rendering, trimming, processing and clean-up operations. Abattoir wastes often contain blood, fat, organic and inorganic solids, and chemicals added during processing operations. In ruminants, the first stomach or paunch contains undigested materials called paunch manure, which can contain long hairs, whole grains and large plant fragments. The faeces of livestock (animal manure) consist of undigested food, mostly cellulose-fibre, undigested protein, excess nitrogen from digested protein, residue from digested fluids, waste mineral matter, worn-out cells from intestinal linings, mucus, bacteria, and foreign matter consumed, calcium, magnesium, iron, phosphorous, sodium, etc. [16]. Abattoir effluent (waste water) has a complex composition and can be very harmful to the environment. Therefore, the importance of knowing the pollution potentials of abattoir wastes especially emission from the burning of hides and skin cannot be over-emphasized. No known study has investigated the emissions from meat processing and its relationship to the incidence of cardio vascular diseases in abattoirs [17]-[21]. Therefore, the aim of this paper is to investigate the relationship between air pollutants and Cardio Vascular Diseases (CVD) occurrence among abattoir workers; identify the predominant factors responsible for the incidence of CVD with a view to recommending possible ways of reducing exposure to and risk of the occurrence of CVD among the abattoir workers in Port Harcourt, Nigeria.

\section{Theoretical Issues and Method of Data Collection}

The theoretical foundation for this study is based on the sophisticated, but rather generalized, web of causation as used by [22] to describe some of the interrelationships among the three major types of cardiovascular diseases. While this web does not attempt to provide a step-by-step description of the mechanisms by which the causal factors operate, it does give a clear view of how different factors may work together to produce one form or another of cardiovascular disease. His web of causation, for example, shows that hereditary tendencies, stress, and lack of physical activity contribute to hypertension (high blood pressure). This is also probably enhanced by atherosclerosis - the buildup of plaque on the inside walls of the arteries. Hypertension, then, in combination with atherosclerosis and the breakdown (lysis) of blood clots (resulting in a free-floating clot within the blood supply_and embolus) may cause a myocardial infarction (heart attack) when the clot lodges in one of the arteries constricted by atherosclerosis and blocks the blood flow to part of the heart muscle. Many contemporary medical problems are better understood in terms of a web of causation. According to this concept, disorders such as heart disease develop through complex interactions of many factors which form a hierarchical causal web of events. These factors may be biophysical, social or psychological and may promote or inhibit the disease at more than one point in the causal process. Ultimately, they determine the level of disease in a community. Since many of these factors can be modified, prevention offers better prospects for health than cure. It is also important to note that many of the factors implicated in heart disease have been identified as increasing the risk of other disorders, such as stroke and cancer. Table 1 indicates the sampled abattoirs and the geographic coordinates where samples were obtained. 
Table 1. Sampled locations and their geographic coordinates.

\begin{tabular}{|c|c|c|c|c|}
\hline \multirow{2}{*}{ Sample stations } & \multirow{2}{*}{$\begin{array}{l}\text { Sampling } \\
\text { points }\end{array}$} & \multirow{2}{*}{ Distance (m) } & \multicolumn{2}{|c|}{ Sampled points co-ordinates } \\
\hline & & & Northing $(\mathrm{N})$ & Easting (E) \\
\hline \multirow{5}{*}{ Trans-Amadi abattoir } & TA1 & 0 & $4^{\circ} 48^{\prime} 49.431$ & $7^{\circ} 2^{\prime} 43.097$ \\
\hline & TA2 & 20 & $4^{\circ} 48^{\prime} 50.102$ & $7^{\circ} 2^{\prime} 44.885$ \\
\hline & TA3 & 50 & $4^{\circ} 48^{\prime} 51.555$ & $7^{\circ} 2^{\prime} 42.203$ \\
\hline & TA4 & 100 & $4^{\circ} 48^{\prime} 53.175$ & $7^{\circ} 2^{\prime} 42.929$ \\
\hline & TA5 & 200 & $4^{\circ} 48^{\prime} 53.734$ & $7^{\circ} 2^{\prime} 43.991$ \\
\hline \multirow{5}{*}{ Rumuokoro } & RM1 & 0 & $4^{\circ} 52^{\prime} 11.915$ & $6^{\circ} 59^{\prime} 56.614$ \\
\hline & RM2 & 20 & $4^{\circ} 52^{\prime} 12.056$ & $6^{\circ} 59^{\prime} 57.886$ \\
\hline & RM3 & 50 & $4^{\circ} 52^{\prime} 12.904$ & $6^{\circ} 59^{\prime} 59.159$ \\
\hline & RM4 & 100 & $4^{\circ} 52^{\prime} 14.176$ & $6^{\circ} 59^{\prime} 55.342$ \\
\hline & RM5 & 200 & $4^{\circ} 52^{\prime} 16.579$ & $6^{\circ} 59^{\prime} 56.473$ \\
\hline \multirow{5}{*}{ Rukpoku } & RK1 & 0 & $4^{\circ} 53^{\prime} 11.006$ & $7^{\circ} 0^{\prime} 3.816$ \\
\hline & RK2 & 20 & $4^{\circ} 53^{\prime} 10.96$ & $7^{\circ} 0^{\prime} 4.334$ \\
\hline & RK3 & 50 & $4^{\circ} 53^{\prime} 11.328$ & $7^{\circ} 0{ }^{\prime} 5.046$ \\
\hline & RK4 & 100 & $4^{\circ} 53^{\prime} 11.891$ & $7^{\circ} 0^{\prime} 4.92$ \\
\hline & RK5 & 200 & $4^{\circ} 53^{\prime} 11.741$ & $7^{\circ} 0 ' 3.989$ \\
\hline \multirow{5}{*}{ Elelenwo } & EL1 & 0 & $4^{\circ} 50 ' 29.042$ & $7^{\circ} 3 ' 53.283$ \\
\hline & EL2 & 20 & $4^{\circ} 50 ' 25.018$ & $7^{\circ} 4^{\prime} 1.975$ \\
\hline & EL3 & 50 & $4^{\circ} 50 ' 32.217$ & $7^{\circ} 3^{\prime} 58.185$ \\
\hline & EL4 & 100 & $4^{\circ} 50 ' 33.733$ & $7^{\circ} 4^{\prime} 3.111$ \\
\hline & EL5 & 200 & $4^{\circ} 50 ' 36.007$ & $7^{\circ} 3^{\prime} 57.428$ \\
\hline
\end{tabular}

TA: Trans-Amadi, RM: Rumuokoro, RK: Rukpokwu, EL: Elelenwo.

The pollutant considered in this study consists of both gases and particulates matter they include $\mathrm{NO}_{2}, \mathrm{SO}_{2}$, $\mathrm{H}_{2} \mathrm{~S}, \mathrm{CH}_{4}, \mathrm{CO}, \mathrm{PM}_{2.5}$, and $\mathrm{PM}_{10}$. All the gases were measured in parts per million (ppm) and converted to milligram per cubic metre $\left(\mathrm{mg} / \mathrm{m}^{3}\right)$ using the equation shown below while the particulate matter was measured in microgram per cubic metre $\left(\mu \mathrm{g} / \mathrm{m}^{3}\right)$ :

$$
\mathrm{Y} \mathrm{mg} / \mathrm{m}^{3}=(\mathrm{X} \text { ppm })(\text { molecular weight }) / 24.45
$$

According to [23] and [24], the sample were taken at the following distances (0, 20, 50, 100, $200 \mathrm{~m})$ to avoid point specific measurement and then averaged to obtain the mean. The target population for the study was meat roasters since they are directly in contact with the thick cloud of smoke at the abattoirs as shown in Table 2. The abattoirs which slaughters fifteen cows and above per day was the criterion used for the selection of the sampled abattoirs. Given this criterion, four abattoirs were selected and used for the study. These includes (1) TransAmadi (2) Rumuokoro (3) Rukpokwu and (4) Elelenwo abattoirs.

A Multi-gas hand held sampler was used to measure air quality at specific points at each of the sampled abattoirs to ascertain the air quality parameters and the concentration levels of pollutants in each of the abattoirs. For reliability of the data, five distances $(0 \mathrm{~m}, 20 \mathrm{~m}, 50 \mathrm{~m}, 100 \mathrm{~m}, 200 \mathrm{~m})$ were taken and averaged to obtain the mean values for each pollutant. The questionnaire approach was also used to obtain both the demographic and socio-economic characteristics of the respondents, duration of job in years, as well as individual frequency of hospital visitation based on symptoms of cardiovascular diseases. The electrocardiogram, a graphic time based record of electrical events in the heart muscle was employed in diagnosing manifestations of ischemic heart disease, i.e., myocardial infarction of the sampled population from the different abattoirs so as to establish a direct link between air pollutants and cardiovascular diseases. The ECG machine used was Cardiart 108T (BPL, India). This was done by placing electrodes (small, plastic patches) at certain locations on the chest, arms, and legs of 
Table 2. Number of workers in the meat roasting section in each sampled abattoir used for the study.

\begin{tabular}{ccccc}
\hline S/no & Location & No of workers & Sample size & Percentage \\
\hline 1 & Elelenwo & 30 & 9 & 18 \\
2 & Rumuokoro & 25 & 8 & 15 \\
3 & Rukpokwu & 15 & 5 & 9 \\
4 & Trans-Amadi & 95 & 29 & 58 \\
5 & Total & 165 & 51 & 100 \\
\hline
\end{tabular}

the sampled abattoir workers. When the electrodes were connected to an ECG machine by lead wires, the electrical activity of the heart of the sampled populations were measured, interpreted, and printed out for the physician's information and further interpretation using Minnesota codes.

Step-Wise Multiple Regression was utilized in analyzing the data. The Multiple Regression Analysis statistical technique was adopted in this study to determine the relationship between the occurrence of cardiovascular diseases as the dependent variable and a set of independent variables such as concentration of pollutants, duration of exposure of workers to pollutants, duration on the job in years, and age of individual workers. Mathematically, step-wise multiple regression is represented thus:

$$
Y=a+\beta_{1} x_{1}+\beta_{2} x_{2}+\beta_{3} x_{3}+\beta_{4} x_{4}+e
$$

where;

$Y$ is the dependent variable (this is the value of $Y$ (occurrence of CVD) when $x_{1}-x_{n}=0$ slope

$Y=$ occurrence of cardiovascular diseases

$x_{1}-x_{5}=$ the explanatory or the independent variables (concentration of pollutants and others such as age of workers, duration of exposure to pollutants, and duration of job.

$\beta_{1}-\beta_{5}=$ value rating for independent variables (regression coefficients).

Using the factors identified above, the function for this study became:

$$
\mathrm{CVD}=\mathrm{f}(\mathrm{CP}, \mathrm{DOE}, \mathrm{JOBD}, \mathrm{AW})
$$

where,

$Y$ is the occurrence of cardiovascular diseases (CVD)

$x_{1}=$ concentration of pollutants (CP)

$x_{2}=$ duration of exposure to pollutants (DOE)

$x_{3}=$ job duration (JOBD)

$x_{4}=$ age of workers (AW)

$e=$ error term

Furthermore, for the assessment of cardiovascular health in the sampled populations, the electrocardiographic graph of individuals obtained through the use of electrocardiogram (ECG) machine at the University of Port Harcourt Teaching Hospital were analyzed by using the "Minnesota code". This scheme of classification of electrocardiographic findings in adult population provided a framework for reporting ECG items in uniform and clearly defined terms.

Code Item

1

2

3

4

5

6

7

8

9

10
Aspect Analysed

Q-wave amplitude

Axis Deviation-QRS-Complex

High amplitude R waves

ST-segment depression

T-wave negativity

AV conduction defect

Ventricular conduction defect

Arrhythmias

Low QRS amplitude

ST segment elevation

Haven examined the technique of analysis used for the study; the map below (Figure 1) shows the sampled 


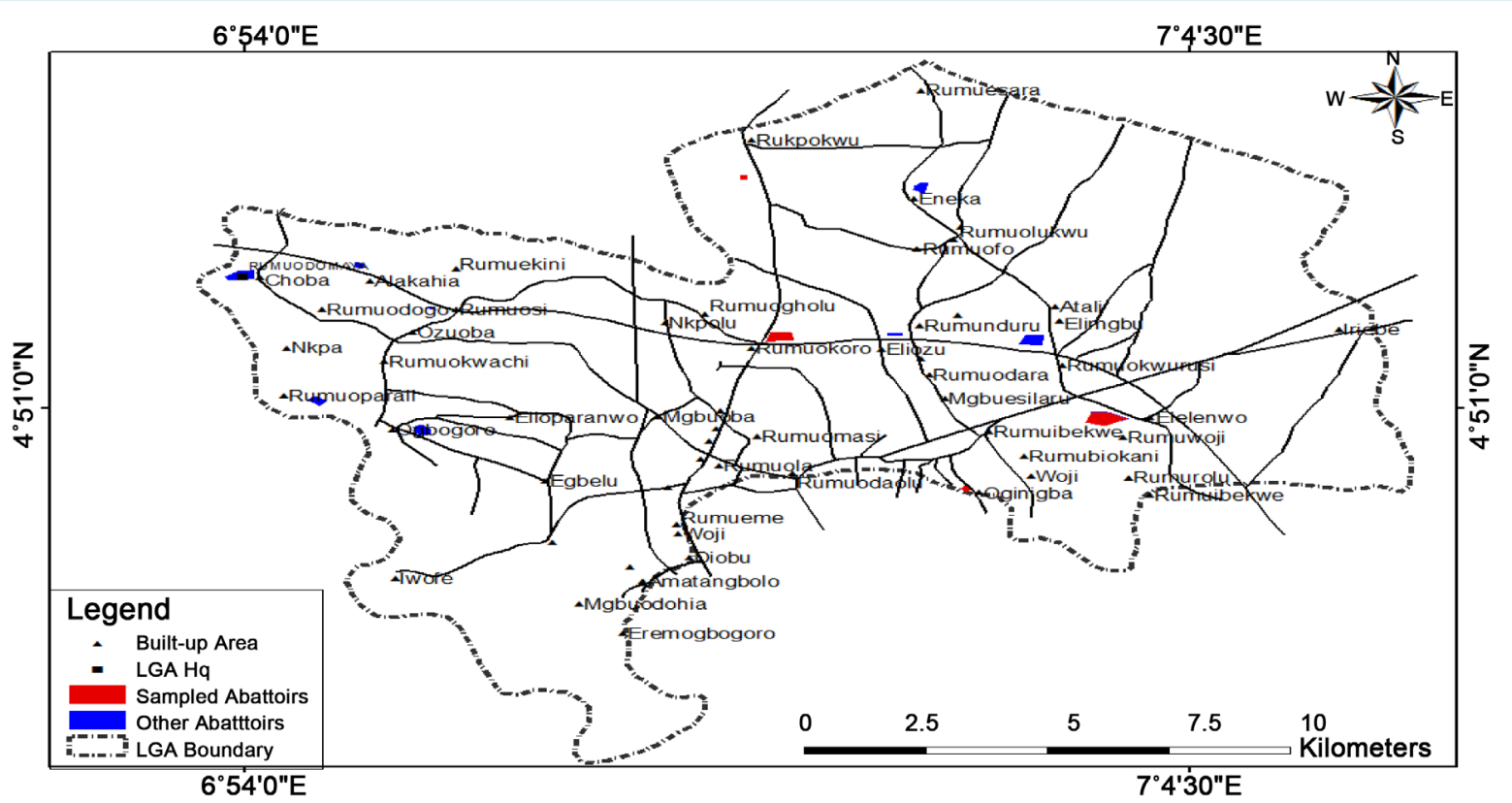

Figure 1. Sampled abattoirs in the study area.

abattoirs used for the study.

\section{Results and Discussion of Findings}

Findings showed that the mean concentration of pollutants at the sampled abattoirs. From the table, it was observed that $0.72 \mathrm{mg} / \mathrm{m}^{3}$ for at the Trans-Amadi (Zoo) abattoir was the highest compared to its concentration at other sampled stations. At Rumuokoro $\mathrm{CO}$ has the overall high mean concentration of $0.77 \mathrm{mg} / \mathrm{m}^{3}$ while $\mathrm{O}_{3}, \mathrm{SO}_{2}$ and $\mathrm{H}_{2} \mathrm{~S}$ values were $0.39,0.26$ and $0.22 \mathrm{mg} / \mathrm{m}^{3}$ respectively. Carbon monoxide mean value of $0.56 \mathrm{mg} / \mathrm{m}^{3}$ for $\mathrm{CO}$ was the highest concentration at Rukpoku abattoir, the case was also the same for Ogbogoro abattoir with CO value of $0.64 \mathrm{mg} / \mathrm{m}^{3}$ having the highest mean concentration. In all the table indicates that the $10.52 \mathrm{mg} / \mathrm{m}^{3}$ for $\mathrm{PM}_{10}$ stand out to be significantly higher compared to other pollutants throughout the study areas, though in other areas the same pollutant are also the most significant. At the Trans-Amadi abattoir, $\mathrm{NO}_{2}$ was absent in the atmosphere while $\mathrm{PM}_{2.5}\left(3.0 \mu \mathrm{g} / \mathrm{m}^{3}\right)$ were relatively high and $\mathrm{PM}_{10}\left(10.52 \mu \mathrm{g} / \mathrm{m}^{3}\right)$ value were quite higher than all others. Table 3 and Table 4 (see attached page) shows the prevalence of different susceptibility factors and ECG findings using Minnesota codes for different age group at different abattoirs respectively. The Table 3 specifically indicated that some of the respondents are either diagnosed hypertensive or diabetic, or had suffered or treated Asthma or Tuberculosis at one time or the other. Table 5 gives a summary of the age distribution of the incidence of CVD in the four studied locations.

From the table, it is clear that there are twenty (25) occurrences of CVD in the studied population at TransAmadi abattoir and this spreads across the different age groups as follows: three (3) in the $11-20$ age group, seven (7) in the 21 - 30 age group, ten (10) in the 31 - 40 age group, three (3) in the 41 - 50 age group and two (2) in the above 50 age group. There are six (6) occurrences of CVD in the population of interest at the Rumuokoro abattoir with four (4) occurrences appearing in the 21 - 30 age group and one (1) occurrence each in the 31- 40 and 41 - 50 age group respectively. The four occurrences recorded at the Rukpokwu abattoir cut across only the 21 - 30 and 31 - 40 age group with two (2) occurrences each respectively. Elelenwo abattoir recorded a total of seven (7) occurrences of CVD out of which three (3) was recorded in the 21 - 30 age group, two (2) in the 31 40 age group and one (1) each in the 41 - 50 and above 50 age groups respectively. Finally, forty occurrences of CVD were recorded in the population of different age groups in the four studied locations and the findings reveals only three (3) of such occurrences in the 11 - 20 age group. Sixteen occurrences of CVD were found in the 21 - 30 age group, fourteen recorded in the 31 - 40 age, five (5) in the 41 - 50 age group and lastly three (3) in the above 50 age group. From all indication, the 21 - 30 age group with sixteen occurrences appear to be the highest which implies that they are the most vulnerable among the age groups that work in the abattoir. 
Table 3. Prevalence of different susceptibility factors of different age groups in the four study locations.

\begin{tabular}{|c|c|c|c|c|c|c|c|c|c|c|c|c|c|c|c|c|c|c|c|c|c|c|c|c|}
\hline \multirow{2}{*}{$\begin{array}{l}\text { Susceptibility } \\
\text { factors }\end{array}$} & \multicolumn{4}{|c|}{$11-20 \mathrm{yrs}$} & \multicolumn{4}{|c|}{21 - 30 yrs } & \multicolumn{4}{|c|}{$31-40$ yrs } & \multicolumn{4}{|c|}{$41-50 \mathrm{yrs}$} & \multicolumn{4}{|c|}{50 yrs and above } & \multicolumn{4}{|c|}{ Total } \\
\hline & TA & $\mathrm{RM}$ & RK & EL & $\mathrm{TA}$ & $\mathrm{RM}$ & RK & EL & TA & $\mathrm{RM}$ & RK & EL & TA & $\mathrm{RM}$ & RK & EL & $\mathrm{TA}$ & RM & RK & EL & TA & $\mathrm{RM}$ & RK & EL \\
\hline $\begin{array}{l}\text { Diagnosed } \\
\text { Hypertension }\end{array}$ & 0 & 1 & 0 & 0 & 3 & 0 & 0 & 1 & 1 & 1 & 1 & 1 & 0 & 1 & 0 & 1 & 2 & 1 & 0 & 1 & 5 & 4 & 1 & 4 \\
\hline $\begin{array}{l}\text { diagnosed } \\
\text { Diabetes }\end{array}$ & 0 & 0 & 0 & 0 & 0 & 0 & 0 & 0 & 0 & 0 & 0 & 0 & 0 & 0 & 0 & 0 & 1 & 0 & 0 & 0 & 1 & 0 & 0 & 0 \\
\hline \multicolumn{25}{|l|}{$\begin{array}{l}\text { Suferred or } \\
\text { treated }\end{array}$} \\
\hline Asthma & 0 & 0 & 0 & 0 & 1 & 1 & 1 & 1 & 0 & 1 & 0 & 1 & 2 & 1 & 1 & 1 & 0 & 0 & 0 & 0 & 2 & 3 & 2 & 3 \\
\hline Stroke & 0 & 0 & 0 & 0 & 0 & 0 & 0 & 0 & 0 & 0 & 0 & 0 & 0 & 0 & 0 & 0 & 0 & 0 & 0 & 0 & 0 & 0 & 0 & 0 \\
\hline Tuberculosis & 0 & 0 & 0 & 0 & 0 & 0 & 0 & 0 & 0 & 0 & 0 & 0 & 0 & 0 & 0 & 0 & 1 & 1 & 1 & 1 & 1 & 1 & 1 & 1 \\
\hline \multicolumn{25}{|l|}{ Family History } \\
\hline Hypertension & 4 & 1 & 2 & 0 & 2 & 0 & 1 & 0 & 1 & 2 & 0 & 1 & 0 & 0 & 0 & 0 & 2 & 1 & 0 & 1 & 9 & 4 & 3 & 2 \\
\hline Diabetes & 1 & 3 & 1 & 0 & 2 & 0 & 1 & 0 & 0 & 1 & 0 & 0 & 1 & 0 & 0 & 1 & 0 & 0 & 0 & 0 & 4 & 4 & 2 & 1 \\
\hline Heart Problems & 0 & 1 & 0 & 0 & 0 & 0 & 0 & 0 & 1 & 0 & 0 & 0 & 0 & 0 & 0 & 0 & 1 & 1 & 0 & 0 & 2 & 2 & 0 & 0 \\
\hline Stroke & 1 & 1 & 0 & 0 & 0 & 0 & 0 & 0 & 0 & 0 & 0 & 0 & 0 & 1 & 0 & 0 & 0 & 0 & 0 & 0 & 1 & 2 & 0 & 0 \\
\hline Cancer & 0 & 0 & 0 & 0 & 0 & 0 & 0 & 0 & 0 & 0 & 0 & 0 & 0 & 0 & 0 & 0 & 0 & 0 & 0 & 0 & 0 & 0 & 0 & 0 \\
\hline Any Others & 1 & 0 & 0 & 1 & 0 & 1 & 1 & 0 & 1 & 0 & 1 & 0 & 0 & 0 & 0 & 0 & 0 & 0 & 0 & 0 & 2 & 1 & 2 & 1 \\
\hline
\end{tabular}

TA: Trans-Amadi; RM: Rumuokoro; RK: Rukpoku; EL: Elenlewo.

Table 4. Occurrence of cardiovascular diseases in the population of different age groups in the four study locations.

\begin{tabular}{|c|c|c|c|c|c|c|c|c|c|c|c|c|c|c|c|c|c|c|c|c|c|c|c|c|c|}
\hline \multirow{2}{*}{$\begin{array}{c}\text { ECG } \\
\text { Findings }\end{array}$} & \multirow{2}{*}{$\begin{array}{c}\text { Minnesota } \\
\text { Code }\end{array}$} & \multicolumn{4}{|c|}{$11-20$} & & \multicolumn{3}{|c|}{$21-30$} & \multicolumn{4}{|c|}{$31-40$} & & \multicolumn{3}{|c|}{$41-50$} & \multicolumn{4}{|c|}{50 and above } & \multicolumn{4}{|c|}{ All age groups } \\
\hline & & TA & $\mathrm{RM}$ & RK & $\mathrm{EL}$ & TA & RM P & RK I & EL ? & TA I & RM R & RK E & EL T & TA & $\mathrm{RM}$ & RK & EL T & TA F & RM & RK $\mathrm{E}$ & EL & $\mathrm{TA}$ & $\mathrm{RM}$ & RK & EL \\
\hline Q-Wave Amp. & 1 & 1 & 0 & 0 & 0 & 1 & 0 & 0 & 0 & 1 & 0 & 1 & 0 & 0 & 0 & 0 & 0 & 1 & 0 & 0 & 0 & 4 & 0 & 1 & 0 \\
\hline $\begin{array}{l}\text { Axis Deviation } \\
\text { QRS-Complex }\end{array}$ & 2 & 0 & 0 & 0 & 0 & 0 & 0 & 0 & 1 & 1 & 0 & 0 & 0 & 0 & 0 & 0 & 0 & 0 & 0 & 0 & 0 & 1 & 0 & 0 & 1 \\
\hline $\begin{array}{l}\text { High Amp. } \\
\text { R-waves }\end{array}$ & 3 & 0 & 0 & 0 & 0 & 2 & 1 & 0 & 1 & 2 & 0 & 0 & 1 & 1 & 0 & 0 & 0 & 1 & 0 & 0 & 0 & 6 & 1 & 0 & 2 \\
\hline $\begin{array}{c}\text { ST-segment } \\
\text { depression }\end{array}$ & 4 & 1 & 0 & 0 & 0 & 2 & 1 & 1 & 0 & 3 & 1 & 0 & 0 & 1 & 1 & 0 & 1 & 0 & 0 & 0 & 0 & 7 & 3 & 1 & 1 \\
\hline $\begin{array}{c}\text { T-wave } \\
\text { negativity }\end{array}$ & 5 & 0 & 1 & 0 & 0 & 1 & 0 & 1 & 0 & 1 & 0 & 0 & 0 & 0 & 0 & 0 & 0 & 0 & 0 & 0 & 0 & 2 & 1 & 1 & 0 \\
\hline $\begin{array}{c}\text { AV } \\
\text { Conduction } \\
\text { Defect }\end{array}$ & 6 & 0 & 0 & 0 & 0 & 0 & 0 & 0 & 0 & 0 & 0 & 0 & 1 & 0 & 0 & 0 & 0 & 0 & 0 & 0 & 0 & 0 & 0 & 0 & 1 \\
\hline $\begin{array}{l}\text { Ventricular } \\
\text { block }\end{array}$ & 7 & 0 & 0 & 0 & 0 & 0 & 0 & 0 & 0 & 0 & 0 & 0 & 0 & 0 & 0 & 0 & 0 & 0 & 0 & 0 & 0 & 0 & 0 & 0 & 0 \\
\hline Arrhythmias & 8 & 0 & 0 & 0 & 0 & 0 & 1 & 0 & 0 & 0 & 0 & 0 & 0 & 0 & & 0 & 0 & 0 & 0 & 0 & 0 & 0 & 1 & 0 & 0 \\
\hline $\begin{array}{l}\text { Low QRS } \\
\text { amplitude }\end{array}$ & 9 & 0 & 0 & 0 & 0 & 0 & 0 & 0 & 0 & 0 & $0 \quad 0$ & 0 & 0 & 0 & 0 & 0 & 0 & 0 & 0 & 0 & 0 & 0 & 0 & 0 & 0 \\
\hline ST-elevation & 10 & 1 & 0 & 0 & 0 & 1 & 1 & 0 & 1 & 2 & $\begin{array}{ll}0 & 1\end{array}$ & 1 & 0 & 1 & 0 & 0 & 0 & 0 & 0 & 0 & 1 & 5 & 0 & 1 & 2 \\
\hline
\end{tabular}

TA: Trans-Amadi; RM: Rumuokoro; RK: Rukpoku; EL: Elenlewo.

\section{The Relationship between Atmospheric Pollutants and the Occurrence of}

\section{Cardiovascular Diseases at Different Abattoirs}

The correlation matrix (Table 6) of the regression CVD on duration of exposure and pollutants concentration at 
Table 5. Occurrence of CVD in the population of different age groups in the four study locations.

\begin{tabular}{|c|c|c|c|c|c|c|}
\hline \multirow{2}{*}{ Sampled Locations } & \multicolumn{6}{|c|}{ Age in years } \\
\hline & $11-20$ & $21-30$ & $31-40$ & $41-50$ & $>50$ & Total \\
\hline Trans-Amadi & 3 & 7 & 10 & 3 & 2 & 25 \\
\hline Rumuokoro & 0 & 4 & 1 & 1 & 0 & 6 \\
\hline Rukpokwu & 0 & 2 & 2 & 0 & 0 & 4 \\
\hline Elelenwo & 0 & 3 & 2 & 1 & 1 & 7 \\
\hline Total & 3 & 16 & 14 & 5 & 3 & 42 \\
\hline
\end{tabular}

Table 6. Zero-order correlation matrix of the occurrence of CVD on duration of exposure and pollutant concentration at Trans-Amadi abattoir.

\begin{tabular}{|c|c|c|c|c|c|c|}
\hline PARAMETERS & CVD & DOE & $\mathrm{O}_{3}$ & $\mathrm{SO}_{2}$ & $\mathrm{CO}$ & $\mathrm{PM}_{10}$ \\
\hline $\mathrm{CDV}$ & 1.000 & & & & & \\
\hline DOE & $0.379^{*}$ & 1.000 & & & & \\
\hline $\mathrm{O}_{3}$ & $0.054^{+}$ & $0.145^{+}$ & 1.000 & & & \\
\hline $\mathrm{SO}_{2}$ & $0.172^{+}$ & $0.206^{+}$ & $-0.140^{+}$ & 1.000 & & \\
\hline $\mathrm{CO}$ & $0.137^{+}$ & $0.037^{+}$ & $0.414^{+}$ & $-0.018^{+}$ & 1.000 & \\
\hline $\mathrm{PM}_{10}$ & $0.122^{+}$ & $-0.115^{+}$ & $-0.012^{+}$ & $0.297^{+}$ & 0.193 & 1.000 \\
\hline
\end{tabular}

DOE: Duration of exposure. ${ }^{*}$ correlation is significant at the $5 \%$ alpha level (2-tailed). ${ }^{+}$Correlation is not significant at $5 \%$ alpha level (2-tailed).

Trans-Amadi abattoir shows that an increase in the concentration of Ozone (0.05), $\mathrm{SO}_{2}(0.17), \mathrm{CO}(0.13), \mathrm{PM}_{10}$ (0.12) will lead to an increase in cardiovascular diseases among the workers at the abattoir.

Result indicates that the occurrence of cardio-vascular diseases has low, positive and significant association with duration of exposure (0.4) of the abattoir workers to the atmospheric pollutants in the vicinity of the abattoirs. Similarly, the $\mathrm{O}_{3}(0.05), \mathrm{SO}_{2}(0.17), \mathrm{CO}(0.14)$ and $\mathrm{PM}_{10}(\mathrm{O} .12)$ were significant at $95 \%$ confidence level. The correlation matrix showed that the pollutants had very low, positive but non-significant association with the occurrence of cardiovascular diseases at Trans-Amadi abattoir at $(\mathrm{P}>0.05)$. These results implied that the occurrence of cardio-vascular disease do not significantly favour an increase in $\mathrm{O}_{3}, \mathrm{SO}_{2}, \mathrm{CO}$ and $\mathrm{PM}_{10}$ but favours an increase in the duration of exposure of the abattoir workers to the pollutants in the daily activities at the Trans Amadi Area. The vulnerability of the workers to cardio-vascular diseases is brought about by corresponding increase in the concentration of $\mathrm{O}_{3}, \mathrm{SO}_{2}, \mathrm{CO}$ and $\mathrm{PM}_{10}$.

Using the standardized coefficients, the model predicting the occurrence of cardio-vascular diseases to the parameters of duration of exposure and concentrations of the atmospheric pollutants is shown in Equation (9).

$$
\mathrm{CVD}=-3.348+385_{\mathrm{DOE}}-0.041_{\mathrm{O}_{3}}+0.51_{\mathrm{SO}_{2}}+0.116_{\mathrm{CO}}+0.129_{\mathrm{PM} 10}
$$

The analysis of variance of the model shows that with an $\mathrm{F}_{\text {cal }}$ value of 0.858 , with an $\mathrm{R}^{2}$ value of 0.184 , the coefficient of determination revealed that DOE accounts for $18.4 \%$ of the variation in the incidence of CVD among the abattoir workers in Trans-Amadi. This result indicates that $79.1 \%$ of the chances of abattoir workers having CVD are explained by other factors which may include, physiological differences, frequency of visits to the area, the degree and concentration of the atmospheric pollutants, the meteorological conditions of the abattoir which determines to a large extent the level of atmospheric loading of the pollutants. This study supports the findings of [15] [20] [24]-[26]. These studies on epidemiological and clinical evidence which has over the last decade, led to a heightened concern about the potential deleterious effects of ambient air pollution on health and its relation to heart disease and stroke. Of special interest are several environmental air pollutants that includes carbon monoxide, oxides of nitrogen, sulfur dioxide, ozone, lead, and particulate matter ("thoracic particles" $\left[\mathrm{PM}_{10}\right]<10 \mu \mathrm{m}$ in aerodynamic diameter, "fine particles" $\left[\mathrm{PM}_{2.5}\right]<2.5 \mu \mathrm{m}$, and "coarse particles" $\left[\mathrm{PM}_{10}\right.$ to $\mathrm{PM}_{2.5}$ ). These pollutants are associated with increased hospitalization and mortality due to cardiovascular disease, especially in persons with congestive heart failure, frequent arrhythmias, or both. The scatter gram of the 
relationship between the occurrence of cardiovascular diseases and the independent variables in Trans-Amadi abattoir are shown in Figures 2-6.

However, at the Rumuokoro abattoir, the correlation matrix (Figure 7) between the occurrence of cardiovascular diseases and the parameters shows that Carbon monoxide (0.57) and duration of exposure $(0.22)$ were the only variables which had the highest and positive correlation values. DOE and CO were also significant with a t-cal value of 3.18 and 4.0 respectively as against t-crit value of 2.36 respectively.

The $\mathrm{r}^{2}$ statistic showed that $90.7 \%$ of the variation in occurrence of CVD is accounted for by Carbon monoxide concentration and duration of exposure of victims at the Rumuokoro abattoir (Table 7). It is therefore clear that amongst other factors which accounts for the occurrence of cardiovascular diseases, increasing concentration of Carbon monoxide and duration of exposure of victim is one key determinant. This is in tandem with the view of [20] that acute exposure to high concentrations of CO can be fatal due to hypoxia and chronic exposure is associated with cardiovascular attacks, neuro-behavioural, fibrinolytic, and perinatal symptoms. Symptoms of repeated low level exposures include headache, nausea, confusion, motor and sensory performance, chest pain,

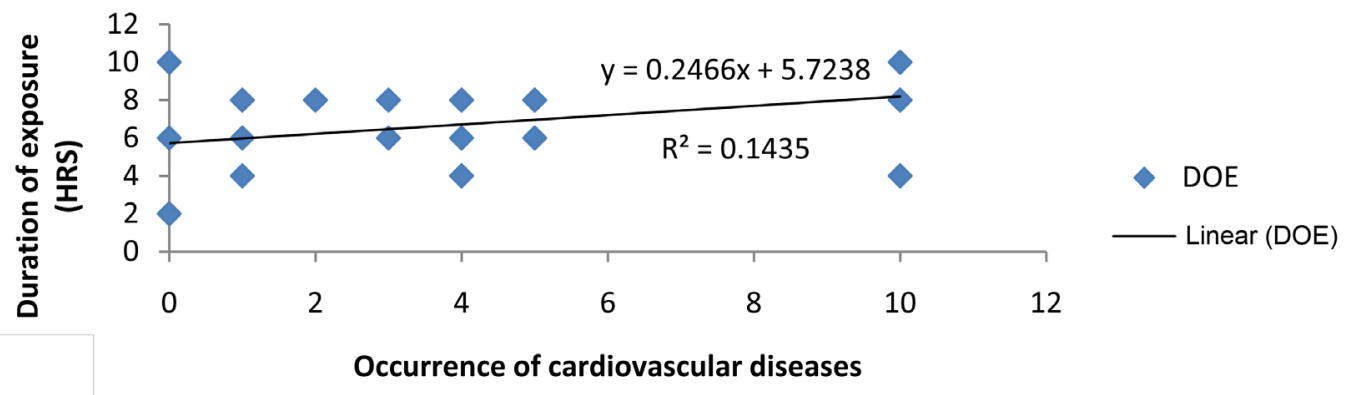

Figure 2. Scattergram of duration of exposure-occurrence of cardio-vascular relationship at Trans-Amadi abattoir.

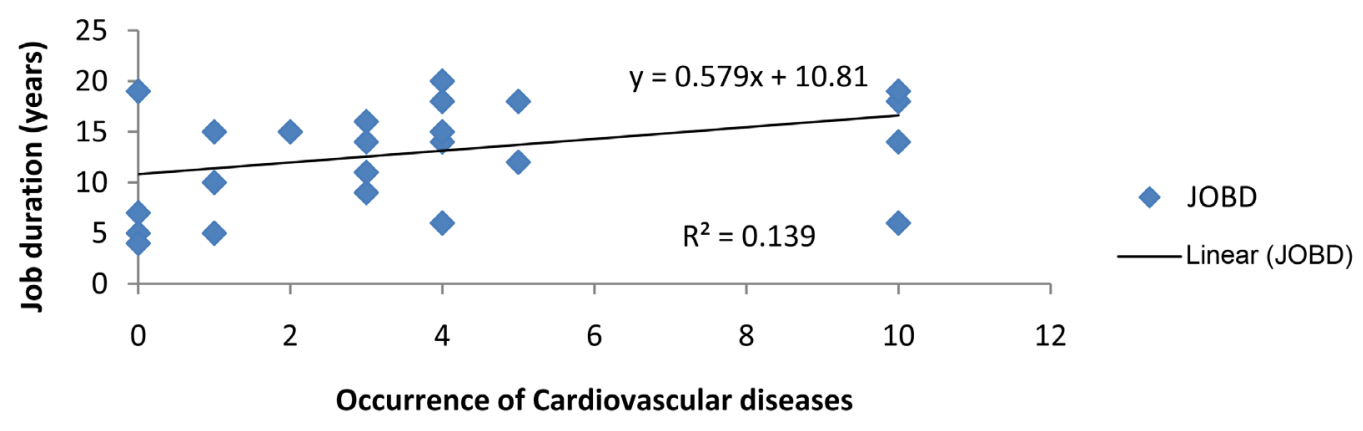

Figure 3. Job duration—occurrence of cardio-vascular diseases relationship at Trans-Amadi abattoir.

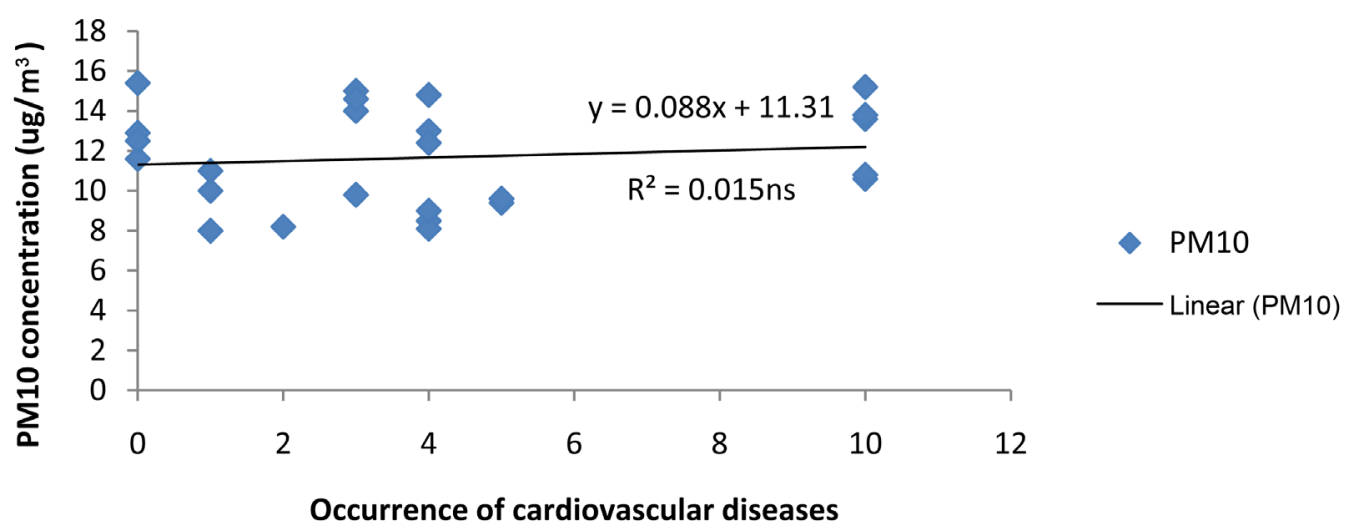

Figure 4. $\mathrm{PM}_{10}$ concentration—occurrence of cardio-vascular diseases relationship at Trans-Amadi abattoir. 


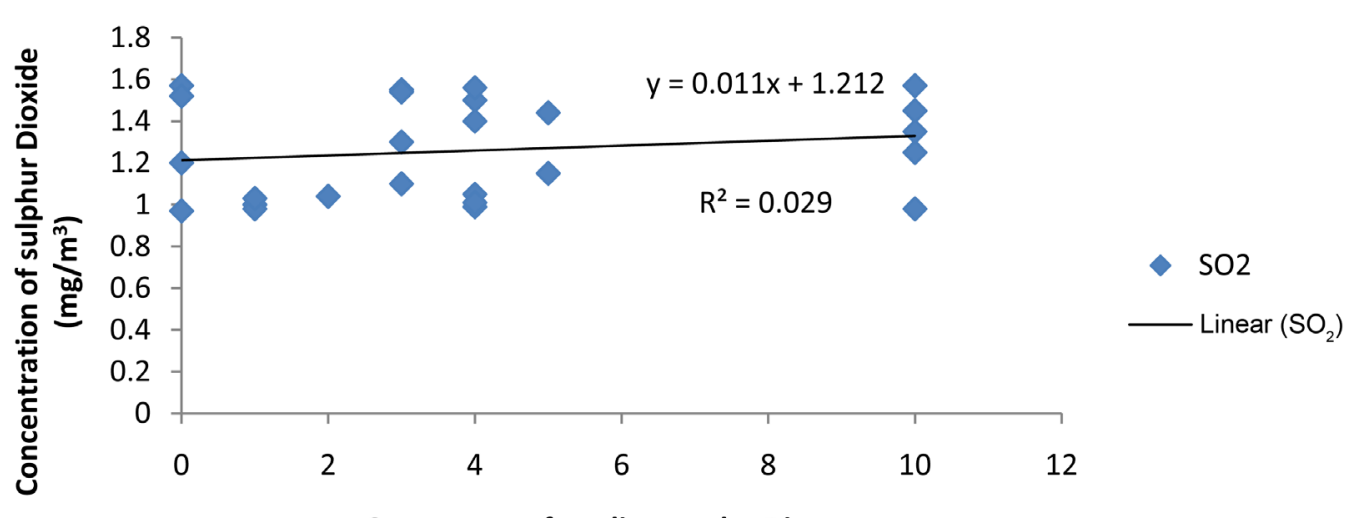

Occurrence of cardiovascular Diseases

Figure 5. $\mathrm{SO}_{2}$ concentration-occurrence of cardio-vascular diseases relationship at Trans-Amadi abattoir.

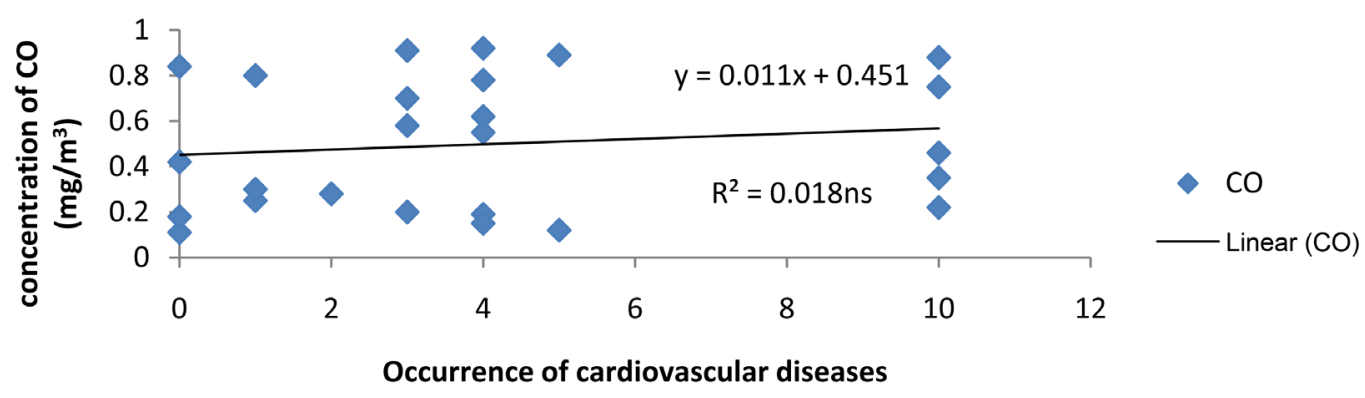

Figure 6. Carbon Monoxide concentration-occurrence of cardio-vascular relationship at Trans-Amadi abattoir.

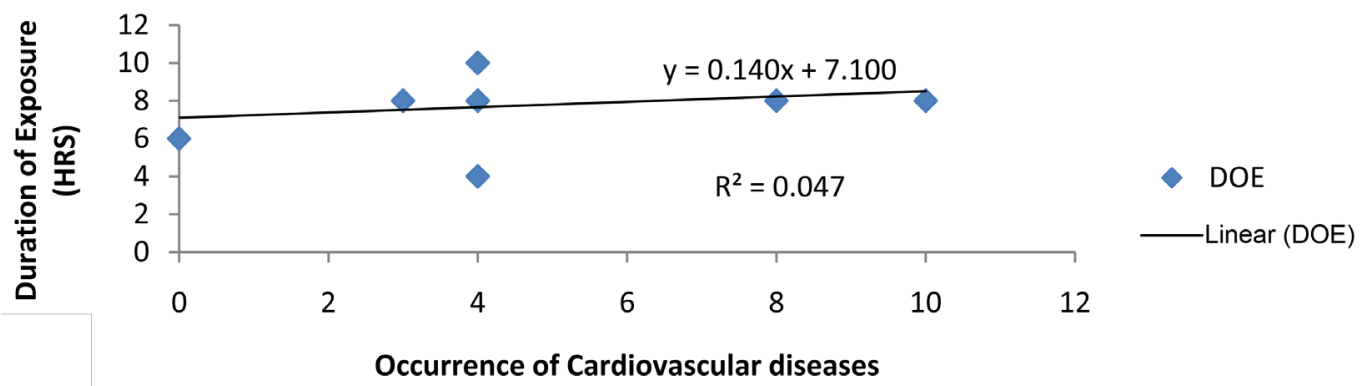

Figure 7. Scattergram of duration of exposure-occurrence of cardio-vascular diseases relationship at Rumuokoro abattoir.

Table 7. Zero-order correlation matrix between occurrence of cardio-vascular diseases and pollutant concentrations at Rumuokoro abattoir.

\begin{tabular}{|c|c|c|c|c|c|c|c|c|}
\hline Parameters & CVD & DOE & $\mathrm{O}_{3}$ & $\mathrm{SO}_{2}$ & $\mathrm{CO}$ & $\mathrm{PM}_{10}$ & $\mathrm{~T}_{\mathrm{cal}}$ & $\mathrm{T}_{\text {crit }}$ \\
\hline $\mathrm{CDV}$ & 1 & & & & & & & \\
\hline DOE & $0.217^{+}$ & 1 & & & & & 3.183 & 2.36 \\
\hline $\mathrm{O}_{3}$ & $0.217^{+}$ & $0.603^{*}$ & 1 & & & & 0.430 & 2.36 \\
\hline $\mathrm{SO}_{2}$ & $-0.268^{+}$ & $0.228^{+}$ & $-0.045^{+}$ & 1 & & & 0.053 & 2.36 \\
\hline $\mathrm{CO}$ & $0.571^{*}$ & $-0.509^{*}$ & $-0.110^{+}$ & $-0.416^{*}$ & 1 & & 4.008 & 2.36 \\
\hline $\mathrm{PM}_{10}$ & $-0.113^{+}$ & $-0.550^{*}$ & $-0.165^{+}$ & $-0.219^{+}$ & $0.144^{+}$ & 1 & 1.470 & 2.36 \\
\hline
\end{tabular}

${ }^{*}$ Correlation is significant at the $5 \%$ alpha level (2-tailed). ${ }^{+}$Correlation is not significant at $5 \%$ alpha level (2-tailed). 
and diarrhea.

The relationship between CVD, and carbon monoxide and duration of exposure is captured in a regression model using the standardized coefficient as shown in Equation (11).

$$
\mathrm{CVD}=-27.34+1.45_{\mathrm{DOE}}-0.45_{\mathrm{O}_{3}}+0.01_{\mathrm{SO}_{2}}+1.29_{\mathrm{CO}}+0.43_{\mathrm{PM} 10}
$$

The scattergram of the relationship between the occurrence of cardiovascular diseases and duration of exposure, job duration, age of workers and the concentration of carbon monoxide are shown in Figures 7-10.

At the Rukpokwu abattoir, the correlation matrix (Table 8) shows that there is an inverse relationship between duration of exposure $(-0.14)$ and particulate matter $(10)$ micron $(-0.18)$ : But age $(0.06), 0_{3}(0.40), \mathrm{SO}_{2}$ (0.23). CO (0.14) correlated directly to the occurrence of CVD. This result implies that as the concentration of these gases increase and age similarly increases, the chances of the abattoir worker been infested with CVD will increase.

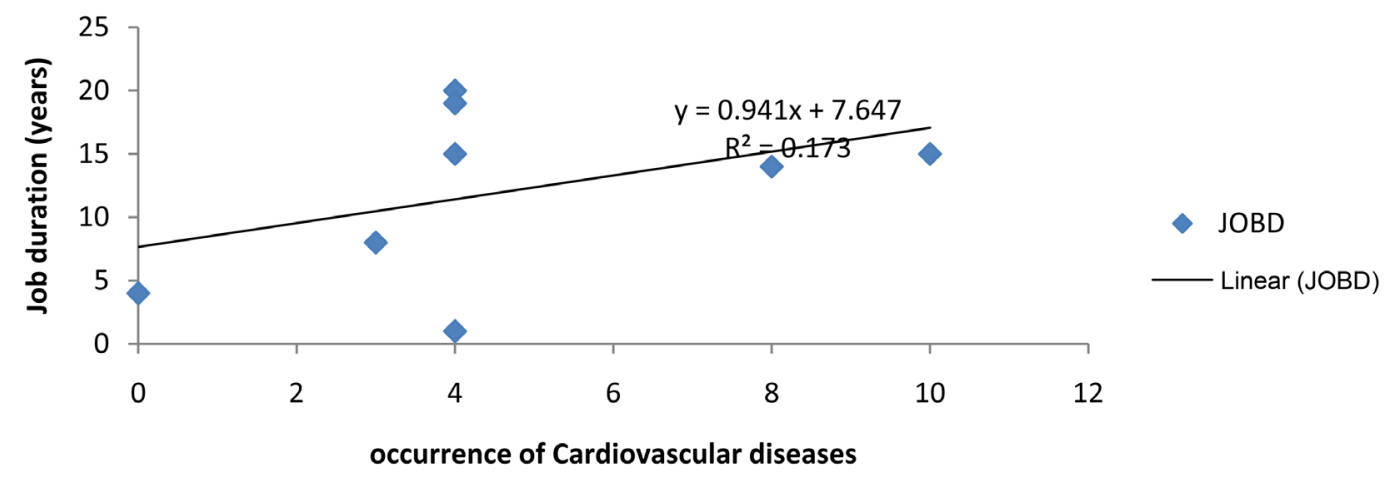

Figure 8. Scattergram of Job duration-occurrence of cardio-vascular diseases relationship at Rumuokoro abattoir.

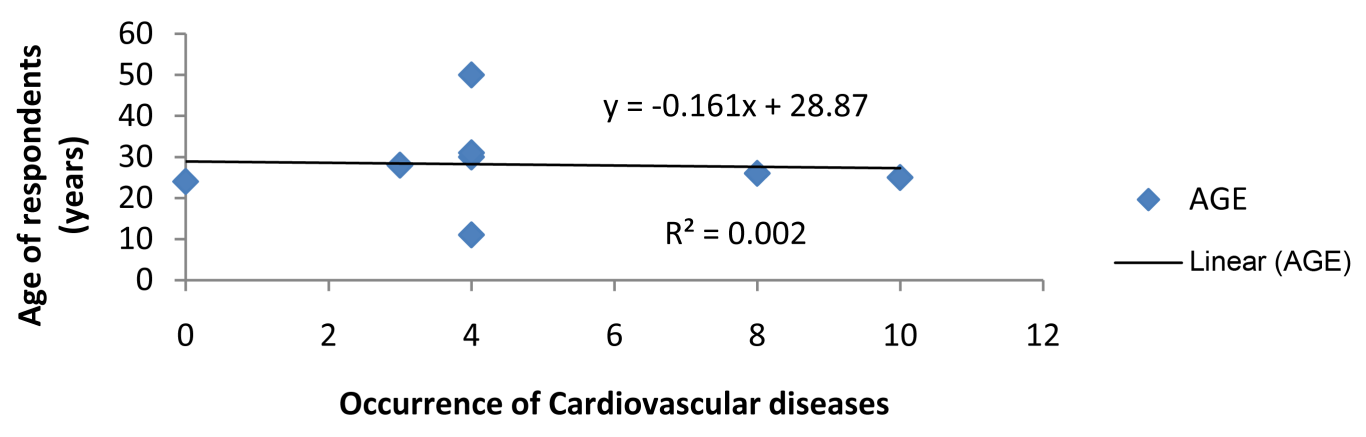

Figure 9. Scattergram of age- occurrence of cardio-vascular diseases relationship at Rumuokoro abattoir.

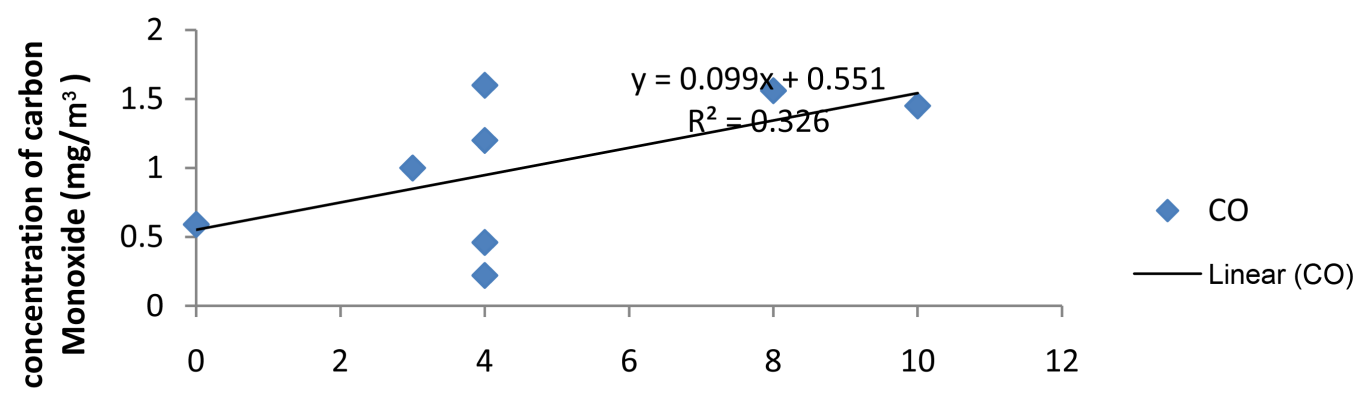

Occurrence of Cardiovascular diseases

Figure 10. Scattergram of carbon monoxide concentration-occurrence of cardio-vascular diseases relationship at Rumuokoro abattoir. 
Table 8. Zero-order correlation matrix for the occurrence of CVD and pollutant and analyzed parameters at Rukpokwu abattoir.

\begin{tabular}{|c|c|c|c|c|c|c|c|}
\hline Parameters & CVD & AGE & DOE & $\mathrm{O}_{3}$ & $\mathrm{SO}_{2}$ & $\mathrm{CO}$ & $\mathrm{PM}_{10}$ \\
\hline $\mathrm{CDV}$ & 1.00 & & & & & & \\
\hline AGE & 0.06 & 1.00 & & & & & \\
\hline DOE & -0.14 & $0.81^{* *}$ & 1.00 & & & & \\
\hline $\mathrm{O}_{3}$ & 0.40 & -0.59 & -0.19 & 1.00 & & & \\
\hline $\mathrm{SO}_{2}$ & 0.23 & -0.12 & 0.37 & $0.74^{*}$ & 1.00 & & \\
\hline $\mathrm{CO}$ & 0.14 & -0.21 & 0.31 & $0.77^{*}$ & $0.99^{* *}$ & 1.00 & \\
\hline $\mathrm{PM}_{10}$ & -0.18 & -0.95 & -0.61 & 0.70 & 0.31 & 0.41 & 1.00 \\
\hline
\end{tabular}

${ }^{*}$ correlation is significant at 0.05 level (2-tailed). ${ }^{* *}$ correlation is significant at the 0.01 level (2 tailed).

Findings indicate that Age and duration of exposure (Age \& DOE); Carbon monoxide (CO) and Sulphur Dioxide $\left(\mathrm{SO}_{2}\right) ; \mathrm{SO}_{2}$ and $\mathrm{O}_{3} ; \mathrm{CO}$ and $\mathrm{O}_{3}$ show significant correlations at different probability levels. DOE and CVD, $\mathrm{PM}_{10}$ and CVD depicts an inverse relationship $(\mathrm{r}=-0.14, \mathrm{p}>0.05)$, $(\mathrm{r}=-0.18, \mathrm{p}>0.05)$ which means that an increase in duration of exposure and concentration of particulates (10) microns will not result to the occurrence of cardio-vascular disease at the Rukpokwu abattoir. This result therefore agrees with the following studies. Excess risk of myocardial infarction or ischemic heart disease was found to be related to increased particle level. This was demonstrated in three studies and as a matter of fact one found that this risk was associated with increased concentrations of $\mathrm{SO}_{2}$ and $\mathrm{CO}$ respectively amongst others. An increase in $\mathrm{SO}_{2}$ was associated in more than half of the studies with increased doctors' house calls and hospital admissions for myocardial infarction, angina, or ischemic heart disease. The association persisted when other pollutants were taken into consideration especially CO [27].

This relationship is captured in a regression model Equation (11);

$$
\mathrm{CVD}=55.01-1.03_{\mathrm{DOE}}+1.27_{\mathrm{O}_{3}}+0.20_{\mathrm{SO}_{2}}-1.75_{\mathrm{PM} 10}
$$

Findings revealed that at the Elelenwo abattoir, the concentration of pollutants and parameters of job duration and duration of exposure shows insignificant and significant as well as low (positive and negative associations among the parameters. However, $\mathrm{SO}_{2}$ and CVD; DOE and age; JOBD and DOE; JOBD and Age show significant correlations at different probability levels. $\mathrm{SO}_{2}$ and CVD Depicts an inverse relationship $(\mathrm{r}=0.62, \mathrm{p}>0.05)$, $\mathrm{O}_{3}$ and CVD ( $\left.\mathrm{r}=0.3, \mathrm{p}>0.05\right)$; CO and CVD ( $\left.\mathrm{r}=0.2, \mathrm{P}>0.05\right)$ which means that an increase in the concentration of $\mathrm{SO}_{2}, \mathrm{O}_{3}$, \& $\mathrm{CO}$ will not lead to the occurrence of CVD and vice versa. Similar strong relationship was observed between DOE and JOBD ( $r=0.91$, $p>0.05)$ as well as Age and JOBD $(r=0.90, p>0.05)$; DOE and Age $(r=0.83, p>0.05)$. The result further shows that CVD has positive associations with age $(r=0.30)$, JOBD (0.13) DOE (0.20), which imply that an increase in age, job duration and duration of exposure will result in the corresponding increase in the occurrence of cardio-vascular diseases at Elelenwo abattoir. However, the high positive relationship between the parameters suggests similar treatment in the same local environment while the negative associations suggest the contrary. The reason for this positive relationship between pollutants concentration, duration of exposure and job is that air pollutants has the capacity to accelerate the development of coronary atherosclerosis and worsen its sequelae. Some of these effects may occur over time (duration of exposure and duration of job), as with acceleration of the progression of atherosclerosis, or rather abruptly, as with the triggering of an arrhythmia or myocardial infarction by acute inflammatory responses, altered platelet adhesiveness, or perhaps vascular endothelial dysfunction. These findings corroborate with other contemporary studies suggesting possible links between acute and/or chronic exposure to pollutants and cardiovascular events may be related to increases in heart rate and blood pressure, fibrinogen, and blood coagulation factors; arterial vasoconstriction; inflammatory mediators (e.g., C-reactive protein [CRP]); endothelial injury/dysfunction; and decreases in heart rate variability (HRV) [28]. Consequences of these effects may include myocardial ischemia (manifested as significant ST-segment depression during exercise testing [29], angina pectoris, or both), malignant ventricular arrhythmias [30], increased plaque vulnerability, and enhanced potential for acute thrombosis triggering acute coronary syndromes. In advancing further reasons for the observed relationship between CVD and 
pollutants concentration, duration of exposure and job in this study, several controlled-exposure studies demonstrate that inhalation of particles [31]-[33] and $\mathrm{O}_{3}$ [34] evokes both a pulmonary and a systemic inflammatory response in humans. One hour of exposure to very high concentrations of diesel exhaust has been shown to induce an inflammatory reaction in the lungs of healthy adults. This response included increased numbers of Polymorph nuclear leukocyte (PMNs), T- and B-lymphocytes, mast cells, and inflammatory mediators [35]. One of these studies showed an increase in adhesion molecules that facilitate the passage of inflammatory cells from the circulation into the airways. In the blood, platelets and PMNs increased, which suggests that exposure to diesel exhaust particles (DEPs) stimulated the bone marrow to release these cells into the circulation [2]. Of note is that the strength of plasma level of fibrinogen to predict cardiac events and death in middle-aged men is modified by the presence of other inflammation-sensitive proteins [36], which suggests that inflammation has a significant role in the determination of cardiovascular risk. In addition, enhanced platelet aggregation may further promote acute thrombosis formation after exposure to diesel exhaust [37] and Ultra Fine Particulates (UFPs) [38]. The mechanisms responsible for platelet activation and fibrinogen elevation remain to be fully elucidated. Nevertheless, these findings support the notion that air pollution can acutely increase the risk of thrombosis, thus promoting ischemic events.

\section{Recommendation}

There should be a deliberate effort to regularly monitor and compare inventory records of pollutant concentrations with emission standards to ascertain 1-hour, 8-hour, 24-hour, quarterly and annual average of the criteria pollutant and others emitted in the abattoir. This should be complimented with enlightenment programmes for purposes of sensitizing and encouraging abattoir worker to understand the health implications of their exposure to emission at the abattoirs. Prevention is likely to provide the most effective gains against highly unpredictable events such as acute myocardial infarction (MI), stroke or arrhythmia; we need to identify more clearly the preventable and the modifiable causes of heart disease. Further studies are urgently needed to: identify the contribution of individual pollutants to specific aspects of cardiovascular disease; establish causality; elucidate the underlying physiological and molecular mechanisms; estimate the relative susceptibility of diseased and healthy individuals and that of specific population groups; and determine whether pollutant exposure and risk correlates.

\section{Conclusion}

This study investigated the spatial analysis of the occurrence of cardiovascular diseases associated with the air quality of selected abattoirs in Port Harcourt, Rivers State. However, the essence of this research was to investigate the factors that influence the occurrence of cardiovascular diseases among abattoir workers in Port Harcourt and to determine the strength of those variables. The study reveals that the occurrence of cardiovascular diseases in the study area is a function of pollutant concentration, duration of exposure to pollutants, age of the worker and daily duration on the job.

\section{References}

[1] Pope III, C.A., Burnett, R.T. and Thun M.J. (2002) Lung Cancer, Cardiopulmonary Mortality, and Long-Term Exposure to Fine Particulate Air Pollution. JAMA, 287, 1132-1141. http://dx.doi.org/10.1001/jama.287.9.1132

[2] Brook, R.D., Franklin, B. and Cascio W. (2004) Air Pollution and Cardiovascular Disease: A Statement for Healthcare Professionals from the Expert Panel on Population and Prevention Science of the American Heart Association. Circulation, 109, 2655-2671. http://dx.doi.org/10.1161/01.CIR.0000128587.30041.C8

[3] Pope III, C.A., Burnett, R.T. and Thurston, G.D. (2004) Cardiovascular Mortality and Long-Term Exposure to Particulate Air Pollution: Epidemiological Evidence of General Pathophysiological Pathways of Disease. Circulation, 109, 71-77. http://dx.doi.org/10.1161/01.CIR.0000108927.80044.7F

[4] Pope III, C.A. and Dockery, D.W. (2006) Health Effects of Fine Particulate Air Pollution: Lines That Connect. Journal of the Air and Waste Management Association, 56, 709-742. http://dx.doi.org/10.1080/10473289.2006.10464485

[5] Brook, R.D., Rajagopalan, S. and Pope, C.A. (2010) Particulate Matter Air Pollution and Cardiovascular Disease: An Update to the Scientific Statement from the American Heart Association. Circulation, 121, 2331-2378. . http://dx.doi.org/10.1161/CIR.0b013e3181dbece1

[6] Nemery, B., Hoet, P.H.M. and Nemmar, A. (2001) The Meuse Valley fog of 1930: An Air Pollution Disaster. The Lancet, 357, 704-708. http://dx.doi.org/10.1016/S0140-6736(00)04135-0 
[7] Bridges, O., Bridges, J.W. and Potter, J.F. (2000) A Generic Comparison of the Airborne Risks to Human Health from Landfill and Incinerator Disposal of Municipal Solid Waste. The Environmentalist, 20, 325-334. . http://dx.doi.org/10.1023/A:1006725932558

[8] Brook, R.D., Brook, J.R. and Urch, B. (2002) Inhalation of Fine Particulate Air Pollution and Ozone Causes Acute Arterial Vasoconstriction in Healthy Adults. Circulation, 105, 1534-1536. . http://dx.doi.org/10.1161/01.CIR.0000013838.94747.64

[9] Batalha, J.R., Saldiva, P.H. and Clarke, R.W. (2002) Concentrated Ambient Air Particles Induce Vasoconstriction of Small Pulmonary Arteries in Rats. Environmental Health Perspectives, 110, 1191-1197. http://dx.doi.org/10.1289/ehp.021101191

[10] Boadi, K.O. and Kuitunen, M. (2003) Municipal Solid Waste Management in the Accra Metropolitan Area, Ghana. The Environmentalist, 23, 211-218. http://dx.doi.org/10.1023/B:ENVR.0000017283.09117.20

[11] Amisu, K.O., Coker, A.O., On, S.L.W. and Isokpehi, R.D. (2003) Arcobacter Butzlieri Strains from Poultry Abattoir Effluent in Nigeria. East African Medical Journal, 80, 218-221.

[12] Tofler, G.H. and Muller, J.E. (2006) Triggering of Acute Cardiovascular Disease and Potential Preventive Strategies. Circulation, 114, 1863-1872. http://dx.doi.org/10.1161/CIRCULATIONAHA.105.596189

[13] Su, T.C., Chen, S.-Y. and Chan, C.-C. (2011) Progress of Ambient Air Pollution and Cardiovascular Disease Research in Asia. Progress in Cardiovascular Diseases, 53, 369-378. http://dx.doi.org/10.1016/j.pcad.2010.12.007

[14] Fullerton, D.G., Bruce, N. and Gordon, S.B. (2008) Indoor Air Pollution from Biomass Fuel Smoke Is a Major Health Concern in the Developing World. Transactions of the Royal Society of Tropical Medicine and Hygiene, 102, 843-851. http://dx.doi.org/10.1016/j.trstmh.2008.05.028

[15] Weli, V.E. (2014) Atmospheric Concentration of Particulate Pollutants and Its Implications for Respiratory Health Hazard Management in Port Harcourt Metropolis, Nigeria. Civil and Environmental Research, 6, 11-17.

[16] Ezeoha, S.L. and Ugwuishiwu, B.O. (2011) Status of Abattoir Wastes Research in Nigeria. Nigerian Journal of Technology, 30, 143-148.

[17] Godleski, J.J., Verrier, R.L. and Koutrakis, P. (2000) Mechanisms of Morbidity and Mortality from Exposure to Ambient Air Particles. Research Report (Health Effects Institute), 91, 5-88; Discussion 89-103.

[18] Wing, S. and Wolf, S. (2000) Intensive Livestock Operations, Health, and Quality of Life among Eastern North Carolina Residents. Environmental Health Perspectives, 108, 233-238. http://dx.doi.org/10.1289/ehp.00108233

[19] Bonetti, P.O., Lerman, L.O. and Lerman, A. (2003) Endothelial Dysfunction: A Marker of Atherosclerotic Risk. Arteriosclerosis, Thrombosis, and Vascular Biology, 23, 168-175. http://dx.doi.org/10.1161/01.ATV.0000051384.43104.FC

[20] Wellenius, G.A., Coull, B.A. and Godleski, J.J. (2003) Inhalation of Concentrated Ambient Air Particles Exacerbates Myocardial Ischemia in Conscious Dogs. Environmental Health Perspectives, 111, 402-408. http://dx.doi.org/10.1289/ehp.5775

[21] Oyedemi, D.T.A. (2004) The Impact of Abattoir Location and Management on Surrounding Residents in Ibadan, Nigeria. M.Tech. Thesis, LAUTECH, Ogbomoso. (unpublished)

[22] Krieger, N. (1994) Epidemiology and Web of Causation: Has Anyone Seen the Spider? Social Science \& Medicine, 39, 887-903. http://dx.doi.org/10.1016/0277-9536(94)90202-x

[23] Routledge, H.C., Ayres, J.G. and Townend, J.N. (2003) Why Cardiologists Should Be Interested in Air Pollution. Heart, 89, 1383-1388. http://dx.doi.org/10.1136/heart.89.12.1383

[24] Efe, S.I. (2006) Particulate Pollution and Its Health Implications in Warri Metropolis, Delta State Nigeria. Env. Anal, 11, 1339-1351.

[25] Zanobetti, A., Schwartz, J. and Sher, D. (2002) Blood Pressure and Heart Rate Associated with PM2.5 in a Cardiac Rehabilitation Study. American Thoracic Society 98th Annual Conference, 17-23 May 2002, Atlanta.

[26] Beaglehole, R. (2001) Global Cardiovascular Disease Prevention: Time to Get Serious. The Lancet, 358, 661-663. http://dx.doi.org/10.1016/S0140-6736(01)05784-1

[27] Monn, C., Naef, R. and Koller, T. (2003) Reactions of Macrophages Exposed to Particles < 10 Microm. Environmental Research, 91, 35-44. http://dx.doi.org/10.1016/S0013-9351(02)00021-X

[28] Donaldson, K., Stone, V. and Seaton, A. (2002) Ambient Particle Inhalation and the Cardiovascular System: Potential Mechanisms. Environmental Health Perspectives, 109, 523-527. http://dx.doi.org/10.1289/ehp.01109s4523

[29] Pekkanen, J., Peters, A. and Hoek, G. (2002) Particulate Air Pollution and Risk of ST-Segment Depression during Repeated Submaximal Exercise Tests among Subjects with Coronary Heart Disease: The Exposure and Risk Assessment for Fine and Ultrafine Particles in Ambient Air (ULTRA) Study. Circulation, 106, 933-938. 
http://dx.doi.org/10.1161/01.CIR.0000027561.41736.3C

[30] Peters, A., Perz, S. and Döring, A. (2000) Activation of the Autonomic Nervous System and Blood Coagulation in Association with an Air Pollution Episode. Inhalation Toxicology, 12, 51-61. http://dx.doi.org/10.1080/08958378.2000.11463199

[31] Ghio, A.J., Kim, C. and Devlin, R.B. (2000) Concentrated Ambient Air Particles Induce Mild Pulmonary Inflammation in Healthy Human Volunteers. American Journal of Respiratory and Critical Care Medicine, 162, 981-988. http://dx.doi.org/10.1164/ajrccm.162.3.9911115

[32] Blomberg, A. and Rudell, B. (2009) Acute Inflammatory Responses in the Airways and Peripheral Blood after ShortTerm Exposure to Diesel Exhaust in Healthy Human Volunteers. American Journal of Respiratory and Critical Care Medicine, 159, 702-709.

[33] Nightingale, J.A., Maggs, R. and Cullinan, P. (2000) Airway Inflammation after Controlled Exposure to Diesel Exhaust Particulates. American Journal of Respiratory and Critical Care Medicine, 162, 161-166. http://dx.doi.org/10.1164/ajrccm.162.1.9908092

[34] Hoek, G., Brunekreef, B. and Goldbohm, S. (2002) Association between Mortality and Indicators of Traffic-Related Air Pollution in the Netherlands: A Cohort Study. The Lancet, 360, 1203-1209. http://dx.doi.org/10.1016/S0140-6736(02)11280-3

[35] Peters, A., Liu, E. and Verrier, R.L. (2000) Air Pollution and Incidence of Cardiac Arrhythmia. Epidemiology, 11, 11-17. http://dx.doi.org/10.1097/00001648-200001000-00005

[36] Lind, P., Hedblad, B. and Stavenow, L. (2001) Influence of Plasma Fibrinogen Levels on the Incidence of Myocardial Infarction and Death Is Modified by Other Inflammation-Sensitive Proteins: A Long-Term Cohort Study. Arteriosclerosis, Thrombosis, and Vascular Biology, 21, 452-458. http://dx.doi.org/10.1161/01.ATV.21.3.452

[37] Nemmar, A., Hoet, P.H. and Dinsdale, D. (2003) Diesel Exhaust Particles in Lung Acutely Enhance Experimental Peripheral Thrombosis. Circulation, 107, 1202-1208. http://dx.doi.org/10.1161/01.CIR.0000053568.13058.67

[38] Nemmar, A., Hoylaerts, M.F. and Hoet, P.H. (2002) Ultrafine Particles Affect Experimental Thrombosis in an in Vivo hamster model. American Journal of Respiratory and Critical Care Medicine, 166, 998-1004.

http://dx.doi.org/10.1164/rccm.200110-0260C 